\title{
Inclusive Education Importance and Problems for Students Social Integration
}

\section{Importancia y problemas de la educación inclusiva para la integración social de los estudiantes}

\author{
Veronika V. Derzhavina \\ Graduate Student of the Institute of Psychology and Education, Kazan (Volga region) Federal University, \\ Kazan, Russia. \\ ORCID ID: 0000-0003-0990-1553
}

Anastasia A. Nikitina

Postgraduate Student of the Department of General and Professional Pedagogics, Orenburg State University, Orenburg, Russia.

ORCID ID: 0000-0002-7609-6104

\begin{abstract}
Alexandr L. Makarov
Department of Physical Education, Ulyanovsk State Agrarian University named after P.A. Stolypin, Ulyanovsk, Russia. ORCID ID: 0000-0002-6696-7260

Olga F. Piralova

Doctor of Education, Professor, Director of the Institute of Management and Economics, Omsk State Transport University, Omsk, Russia.

ORCID ID: 0000-0001-5506-9169
\end{abstract}

\section{Alla A. Korzhanova}

PhD in Education, Associate Professor of the Department of Social and Cultural Activities and Tourism, Gzhel State University, Elektroizolyator, Russia. ORCID ID: 0000-0003-1162-2035

\section{Nadezhda V. Gruver}

$\mathrm{PhD}$ in Pedagogy, Head of the Master's Studies Department, Institute of Legislation and Comparative Law under the Government of the Russian Federation, Moscow, Russia.

ORCID ID: 0000-0003-3578-2252

\section{Nikolay A. Mashkin}

Doctor of History, Professor of the Department of State and Legal Disciplines, Plekhanov Russian University of Economics, Moscow, Russia. ORCID ID: 0000-0003-4890-1791

Received 09-08-20 Revised 10-10-20

* Correspondence

Email: vsizaya@yandex.ru
Accepted 12-12-20 On line 03-12-21

\section{Citation:}

Veronika V. Derzhavina, Anastasia A. Nikitina, Alexandr L. Makarov, Olga F. Piralova, Alla A. Korzhanova, Nadezhda V. Gruver, Nikolay A. Mashkin. (2021). Inclusive Education Importance and Problems for Students Social Integration. Propósitos y Representaciones9 (SPE3), e1130. Doi: http://dx.doi.org/10.20511/pyr2021.v9nSPE3.1130 


\begin{abstract}
The article relevance. Modern concepts of education development, recognition of the uniqueness and self-worth of human individuality have led to the search for ways to socialize individuals with disabilities, to the development of new pedagogical strategies aimed at developing ideas of independent life for this category of the population. The research purpose is to study the features and identify ways to improve the quality of inclusive education. Research methods: as a research method, we used a questionnaire survey as a method of collecting primary information, which allows us to identify various aspects related to the problems of formation and perception of inclusive education by participants in the educational process. Research results: the article describes the peculiarity of the current stage of inclusive education development, analyzes the social mechanisms for improving the quality of inclusive education. The novelty and originality of the research lies in the fact that for the first time the correspondence of the existing model of inclusive education to the needs of a significant part of the educational process subjects was investigated. It is shown that, from the point of view of educational services' consumers, a significant obstacle to improving the quality of inclusive education is the orientation of the education system on results, and not the educational process. It is revealed that the main functions of an inclusive school are educational, career-oriented, educational, and integrative. It is shown that relationships with teachers are a significant factor of psychological stress in inclusive classes. It is found that inclusive classes are sufficiently distanced from interaction with the local community. It is shown that teachers lack the skills of teamwork and confident behavior of the teacher in the presence of another adult in the classroom. It is revealed that the inclusive school is currently characterized by a high level of internal unity, but is not focused on external relations with the local community. It is shown that parents, unlike students, note the creation of an accessible environment only for certain categories of children with disabilities (including children with musculoskeletal disorders), but not for children with sensory disorders (vision and hearing). Practical significance: the data Obtained in this work can be used in psychological research, pedagogical Sciences, age psychology, as well as for further theoretical development of this issue
\end{abstract}

Keywords: students, inclusive education, adaptation, integration.

\title{
Resumen
}

Relevancia del artículo. Los conceptos modernos de desarrollo educativo, el reconocimiento de la singularidad y la autoestima de la individualidad humana han llevado a la búsqueda de formas de socializar a las personas con discapacidad, al desarrollo de nuevas estrategias pedagógicas destinadas a desarrollar ideas de vida independiente para esta categoría de la población. . El propósito de la investigación es estudiar las características e identificar formas de mejorar la calidad de la educación inclusiva. Métodos de investigación: como método de investigación, utilizamos una encuesta cuestionario como método de recolección de información primaria, que nos permite identificar diversos aspectos relacionados con los problemas de formación y percepción de la educación inclusiva por parte de los participantes en el proceso educativo. Resultados de la investigación: el artículo describe la peculiaridad de la etapa actual de desarrollo de la educación inclusiva, analiza los mecanismos sociales para mejorar la calidad de la educación inclusiva. La novedad y originalidad de la investigación radica en que por primera vez se investigó la correspondencia del modelo existente de educación inclusiva con las necesidades de una parte significativa de los sujetos del proceso educativo. Se muestra que, desde el punto de vista de los consumidores de los servicios educativos, un obstáculo importante para mejorar la calidad de la educación inclusiva es la orientación del sistema educativo a los resultados y no al proceso educativo. Se revela que las principales funciones de una escuela inclusiva son educativas, vocacionales, educativas e integradoras. Se demuestra que las relaciones con los profesores son un factor significativo de estrés psicológico en las clases inclusivas. Se encuentra que las clases inclusivas están suficientemente alejadas de la interacción con la comunidad local. Se demuestra que los profesores carecen de las habilidades de trabajo en equipo y del comportamiento confiado del profesor en presencia de otro adulto en el aula. Se revela que la escuela inclusiva se caracteriza 
actualmente por un alto nivel de unidad interna, pero no está enfocada a las relaciones externas con la comunidad local. Se muestra que los padres, a diferencia de los estudiantes, notan la creación de un entorno accesible solo para ciertas categorías de niños con discapacidades (incluidos los niños con trastornos musculoesqueléticos), pero no para los niños con trastornos sensoriales (visión y audición). Importancia práctica: los datos obtenidos en este trabajo pueden ser utilizados en investigación psicológica, ciencias pedagógicas, psicología de la edad, así como para un mayor desarrollo teórico de este tema.

Palabras clave: estudiantes, educación inclusiva, adaptación, integración.

\section{Introduction}

The rehabilitation function of education for persons with disabilities is not in doubt. In the context of dynamically developing social and economic processes of Russian society transformation, education solves the problems not only of protecting the rights of children with disabilities, but also of personal development, social activation in the context of organized public support on the way to true inclusion in social life (Finogenova, 2010; Cherdymova et al., 2019; Korkunov \& Bryzgalova, 2008). Education has a decisive influence on the formation of worldview, value orientations, setting life goals, develops adaptive abilities to changing living conditions, and harmonizes the life of a person with disabilities in society (Akopov, Cherdymova \& Cherdymova, 2003; Volkova, 2002). The consideration of inclusive education becomes important because the very concept describing it, as well as the type of education that designates it, is quite new and borrowed for Russia (Sekovets \& Terekhova, 2008; Vygotsky, 1997; Lapp, 2010; Gavrilushkina, Golovchits \& Egorova, 2001). Russia has not yet established a unified interpretation of the concept of inclusive education. Understanding education as a public good is characteristic of the concept of a social state, which should provide its citizens with equal opportunities to access social values (Ananyev, 2001; Cherdymova, 2018, Edenbaum \& Gostar, 2008; Booth \& Ainscow, 2007). Receiving quality education for children with disabilities contributes to their social security at all stages of socialization, improving their social status, becoming a civic consciousness and being able to actively participate in public life and work. High-quality education for students with disabilities means that they are created conditions for variable entry into certain social roles, expanding the scope of freedom of choice in determining their life path. Thus, the problem of successful social rehabilitation of children with disabilities is largely due to the organization of the process of obtaining high-quality General education as the basis for subsequent socialization (Churakova, 2007; Suslov, 2008; Yarskaya-Smirnova \& Loshakova, 2003).

Currently, increasing attention is being paid to the development of inclusive education as an evolutionary measure designed to promote greater access to quality education for students with different educational needs, including children with disabilities (Solovyova, 2010; Zykova, 2005; Malofeev, 1997). The transition to inclusive education in the domestic context as a General vector of reform is consistent with the trends in the development of international practice of education for children with disabilities and the legislation that enshrines these practices. At the same time, in many countries, including Russia, there is a serious barrier to the development of inclusive education in the form of insufficient readiness of the education system to develop and implement individual educational routes within the inclusive model (Ilyina, 2007; Kolominsky, 2000; Zotova, 1997; Schmidt, 2004; Karpova, Yarskaya-Smirnova \& Karpova, 2008). Currently, the problem of the quality of inclusive education as a promising, but only emerging practice is rather related to ensuring the necessary level of this quality, rather than improving the quality, i.e. exceeding the considered standard level. At the same time, the solution of these two interrelated tasks (ensuring and improving the quality of inclusive education) is possible if an effective system of quality management of inclusive education is built (Voznyak \& Dubinina, 2009; Dimenshtein \& Larikova, 2000; Sorokin, 2002; Romanova, Yarskaya-Smirnova \& Galakhova, 2007). Today the realistic nature of proposals offered to solve the problems in Russia is conditioned by the existence of the legislative opportunities for the development of inclusive education, a high need of different communities of persons with disabilities to expand access to education, the experience of the individual implemented programs of inclusive education in Russia, the experience of educational policy studies and special 
education, the authority of members of the movement for inclusive education among civil society, researchers, social policy and government representatives.

\section{The Study Objectives and Structure}

Prior to the analysis of the research methodology, it should be noted that improving the quality of inclusive education implies exceeding the quality level stated in educational standards and outstripping the expectations of consumers of educational services. Improving the quality of inclusive educational services can be understood as an integral characteristic of indicators and features that reflect the growth of the level of the process and results of inclusive education in accordance with the requirements of educational standards and consumers of educational services. The most important epistemological characteristic of inclusive education is the inapplicability of the usual procedures for assessing its quality, based on a direct comparison of educational results with educational standards. Particular importance in the study of improving the quality of inclusive education should be given to the assessment of the procedural features of education, its educational aspects and the personal significance of the results, learning to act in situations of difference, not repetition. An inclusive education quality criterion is the versatile success of a child who has become more experienced, independent, and responsible.

After conducting a pilot study, it was found that $13 \%$ of parents of students identify the concepts of quality of education and quality of teaching or professionalism of teachers. Nearly the same number of respondents $(11 \%)$ associate the quality of education with the social adaptation of the child in society. The level of development of the material and technical base of the school and the psychological atmosphere in it are considered rather as a favorable background, a prerequisite for quality education, and not its direct indicator. This is the most common opinion among teachers who answered this question, which is associated with the identification of the quality of education and good knowledge of students (31\%). Teachers emphasized that it is the intellectual development of students, and not just preparing for exams, and it is the task of the school. Some teachers associate the quality of school education with the possibility of entering a University (7\%). Almost the same number of respondents ( $9 \%$ ) have ideas about quality education related to the concept of personalityoriented education.

\section{Features of Perception of Inclusive Education by Participants of the Educational Process}

Analyzing the responses of students, their parents and teachers to these questions, we can conclude that the generalized view of the subjects of the educational process about quality education includes the following components: provision of modern material and technical equipment (11\%); erudite and emotionally responsive teachers (25\%); a high level of theoretical training, moral and legal education (21\%); positive personal development of students (43\%). Thus, a serious obstacle to the development of inclusive education and improving its quality is the dominance of uniform, standardized teaching methods and tools, and the lack of direct interweaving of socializing influence in the educational process. The highest level of satisfaction with the quality of school education was recorded among teachers $(61 \%)$, and the lowest among parents of students $(31 \%)$. Less than half of the respondents in all categories have a high level of satisfaction with the quality of education. We can talk about the discrepancy between the existing model of education and the needs of a significant part of the subjects of the educational process, including direct consumers of educational services. Summarizing what has been said about trends in the development of education and their connection with inclusive practices, it should be emphasized that: the development of inclusive education is consistent with the requirement for school education to be more focused on the interests of the student. In the context of expanding the range of expectations from education for all categ ories of respondents, the meaning of inclusive education as individualizing is updated; students and parents have a clear request to improve the quality of the educational process; a significant obstacle to improving the quality of inclusive education is the orientation of the education system on results, not the educational process. At the same time, the results are actually identified with the quality of students' knowledge (76\%). The main functions of an inclusive school were educational $(41 \%)$, upbringing $(53 \%)$, integrative $(13 \%)$, career guidance $(21 \%)$, and of communication space 
organization (41\%). The educational function includes broadcasting academic knowledge, as well as familiarizing teachers and parents with the age-specific personal development of children with disabilities and children without disabilities. Informants define the educational function as the formation of a certain system of values, ensuring social adaptation of children with disabilities, a positive attitude to these children of children without disabilities. The integrative function, in turn, includes an understanding of the idea of children's team building. The career guidance function is associated with determining the professional orientation of the student, which helps to imagine more clearly the professional future of both healthy children and children with disabilities and facilitates socialization. The function of organizing a communication space is to provide opportunities for communication between children with disabilities and healthy children and conduct training sessions. Informants in their responses emphasized that the inclusive school today faces significant problems in its development due to the lack of standards and regulations (financial, educational, etc.) of inclusive education. To improve the quality of inclusive education, it is necessary to accept a child with disabilities into the team, provide daily support, help in learning, and positive emotional and behavioral responses in communicating with a child with disabilities. According to the observations of teachers and school psychologists, the attitude of classmates to children with different types of disabilities is far from the same. In the context of improving the quality of inclusive education, it is necessary to include in the program of advanced training courses for teachers not only the traditional educational module, but also training in communication skills, the ability to work with other teachers in the format of one lesson, jointly develop comprehensive curricula and plans, personal qualities and properties, readiness for innovations, flexibility of thinking, psychological resistance to failures. Traditionally, the focus in inclusive classes is on ensuring the psychological comfort of children. However, to improve the quality of inclusive education, it is important to focus on reducing the psychological stress of teachers who are forced to adapt to a different learning model. A special role in the training of an inclusive schoolteacher should be played by familiarity with modern educational technologies and encouragement of their use by the school administration. Relationships with teachers are much more a factor of psychological stress in inclusive classes. Therefore, students in their responses drew attention to the fact that the personal attitude of teachers to them affects their academic performance $(79 \%)$.

Thus, the negative attitude towards a child with disabilities in an inclusive class today is less associated with the fact of disability, and more with possible educational difficulties derived from disability. This refutes the generally accepted assumption that the main risk of an inclusive class is the possibility of a child with disabilities facing negative peer attitudes. Improving the quality of inclusive education today is associated with the search for ways to harmonize teacher - student relations. It is found that inclusive classes are sufficiently distanced from interaction with the local community. As for teachers, they noted that there is an element of competition in their professional environment. In terms of improving the quality of inclusive education, this makes it difficult for a team of specialists to support children's education in inclusive classes. Thus, today teachers lack the skills of teamwork and confident behavior of the teacher in the presence of another adult in the classroom.

Summarizing what has been said about building a school community as a condition for improving the quality of inclusive education, we emphasize that an inclusive school is currently characterized by a high level of internal unity, but is not focused on external relations with the local community. An inclusive school should not seek to become a universal source of support for children with disabilities. In terms of adopting inclusive values to develop an inclusive culture, students can see the school's support for the ideas of tolerance and ensuring the right of children with disabilities to education (73\%). Students, their parents and teachers approve the education of children with disabilities in secondary schools. The work of the team of inclusive schools in the organization of basic and General education is highly appreciated: to improve the performance of students and to try to attract all students in extracurricular, creative activities. Thus, in terms of improving the quality of inclusive education, it is important that teachers try to include all students in the educational process. 
Thus, improving the quality of inclusive education today requires solving the problem of changing perceptions about the goals of this education. Teachers need to be convinced that it is possible to create a situation of success in school for each student. In the meantime, teachers consider outstanding achievements in any field as school achievements. It is necessary to evaluate the individual progress of each student, and not compare it with some abstract norm.

Parents, in contrast to students, noted that the school created an accessible environment only for certain categories of children with disabilities - for children with musculoskeletal disorders $(71 \%)$. The school is poorly prepared for teaching children with sensory impairments (vision and hearing) (100\%). A similar point of view was expressed by teachers, who stressed that children with sensory impairments and their parents rarely make the decision to study in a comprehensive school, which hinders the equipping of schools in accordance with their needs.

Regarding the effective management of school resources as part of the development of inclusive practice by students, it is emphasized as a positive point that the personal qualities of teachers are involved as a resource in the learning process (79\%). Having an emotional involvement in the work process helps you find the right teaching methods. As a result, all students, not just excellent students, are not afraid to answer in class, Express their opinions, and perform new learning tasks. However, the tasks for students are often the same. Consequently, the issue of improving the quality of inclusive education is also related to the search for new, differentiated forms of testing students' knowledge, including at the level of final certification at school graduation, with time and human resources for developing individual educational routes. Parents of students in inclusive classes stressed that their children did not have trouble in communicating with students with disabilities and perceive them as equals. Teachers noted that improving the quality of inclusive education is hindered by focusing on the medical model of disability in the preparation of advanced training courses. At the same time, even teachers do not dispute the fact that teachers do not often use different forms of training in the classroom, working in groups, and not front-line teaching methods. Tasks for reproducing information received from the teacher are more often used than tasks for independent study. Most teachers use ready-made teaching methods. Even today, the organized interaction of participants in the educational process can provide such positive effects of inclusion as the unity of the children's team and building a comprehensive psychological and pedagogical support for the education of a child with disabilities in an inclusive class.

\section{Conclusions}

To move from the current stage of improving the quality of inclusive education to the next one, which is associated with the large-scale spread of inclusive practices, it is necessary to standardize inclusive education.

Summarizing the results of the analysis, we can formulate the principles for developing standards for inclusive education: measures taken in the field of education of children with disabilities should be based on professional knowledge of the learning conditions and educational needs of disabled people; the main aspects of educational policy for disabled people should be clearly defined; policy decision-making procedures necessary to ensure equal educational opportunities for persons with disabilities should be consistent with the technical and economic resources of the school and should be based on an understanding of the cultural context and the ability of persons with disabilities to participate in these decisions.

From the point of view of consumers of educational services, a significant obstacle to improving the quality of inclusive education is the orientation of the education system towards results, rather than the educational process. Relationships with teachers are a significant factor of psychological stress in inclusive classes. Inclusive classes are sufficiently distanced from interaction with the local community; teachers lack the skills of teamwork and confident behavior of the teacher in the presence of another adult in the classroom. 
It can be concluded that the inclusive school is currently characterized by a high level of internal unity, but is not focused on external relations with the local community. Parents, unlike students, note the creation of an accessible environment only for certain categories of children with disabilities (for children with musculoskeletal disorders), but not for children with sensory disorders (vision and hearing).

However, the problem of improving the quality of inclusive education is not articulated as a holistic phenomenon, which is reflected in the actual lack of a clear definition of improving the quality of inclusive education.

Thus, the problematic situation of research on the formation of inclusive education is in contradiction between the growth of practices of inclusive educational services and the lack of a unified theoretical framework for regulating these practices and generalizing them in the form of quality standards for inclusive education, which stimulate not only the maintenance of guaranteed quality of such services, but also its improvement in accordance with the needs of dynamically developing practice of inclusion.

\section{References}

Akopov, G.V., Cherdymova, E.I. \& Cherdymova, Z.I. (2003). Research of ecological consciousness formation in unity with ecological and ethical attitude to objects of nature. Research in the field of biology and methods of teaching it. Interuniversity collection of scientific papers. Samara state pedagogical University, 204-209.

Ananyev, B.G. (2001). Man as a subject of knowledge. St. Petersburg: Piter.

Booth, T. \& Ainscow, M. (2007). Inclusion Indicators. Practical guide: M. Perfilyeva. Moscow: Regional public organization for the disabled "Perspektiva".

Cherdymova, E.I. (2018). Ecology of childhood. Childhood of the XXI century: socio-humanitarian thesaurus. Thematic dictionary-reference, 1, 129-131.

Cherdymova, E.I., Lipen, S.V., Kornev, A.V., Ovchinnikova, L.I., Ovchinnikov, A.A., Stolyarova, A.N., Tyutyunnik, I.G. \& Vilskaya, N.V. (2019). Explanation of donation: advantages and downsides. International Journal of Applied Exercise Physiology, 2(1), 475-481.

Churakova, S.N. (2007). Preparing students for integrated education of children with developmental problems in the General education class. School speech therapist, 5, 13-22.

Dimenshtein, R.P. \& Larikova, I. V. (2000). Integration of a special child in Russia: legislation, practice and prospects. Special child: research and experience of assistance, 3, 27-64.

Edenbaum, E.L. \& Gostar, A.A. (2008). Formation of cognitive activity of children with mild mental underdevelopment in different psychological and pedagogical conditions. Defectology, 5, 410.

Finogenova, M.E. (2010). Features of building interpersonal relationships and their influence on the process of socio-psychological adaptation of girls with intellectual disabilities. Defectology, $1,31-37$.

Gavrilushkina, O.I., Golovchits, L.A. \& Egorova, M.A. (2001). Psychological aspects of special education and new correctional programs and technologies. Psychological science and education, 1, 79-88.

Ilyina, Y.A. (2007). study of the relationships with peers in preschool children with moderate mental retardation in terms of an integrative environment. Defectology, 4, 18 -26.

Karpova, G.G., Yarskaya-Smirnova, E.R. \& Karpova, G.G. (2008). Sociocultural practice in relation to disabled people: from legislation to public opinion. Education for all: policy and practice of inclusion. Saratov, 25-33.

Kolominsky, Ya.L. (2000). Psychology of relationships in small groups. Minsk: Tetrasistems.

Korkunov, V.V.n \& Bryzgalova, S.O. (2008). Pedagogical problems of individualization and integration of children with intellectual disabilities in school education. Special education, $12,27-32$.

Lapp, E.A. (2010). Integration of General and special education: regional context: results of the project Inclusive education - education strategy for all. Social pedagogy, 5, 107-113. 
Malofeev, N.N. (1997). Current stage in the development of the special education system in Russia: research results as a basis for building a development program. Defectology, 4, 315-326.

Romanova, P., Yarskaya-Smirnova, E. \& Galakhova, A. (2007). Right to life in society: mechanisms of educational integration of disabled children: scientific report. Saratov: publishing house "Scientific book".

Schmidt, V.R. (2004). Interdisciplinary approach to the problem of social exclusion. Journal of social policy research, 2(4), 547-566.

Sekovets, L.S. \& Terekhova, A.V. (2008). Methodological recommendations for training of students under the program of special (correctional) schools of VIII type in secondary school. Practice of administrative work at school, 1, 43-45.

Solovyova, T.A. (2010). Special educational needs of integrated schoolchildren with hearing impairment. Defectology, 4, 27-32.

Sorokin, P.A. (2002). Social Analytics. Analysis of elements-interactions. Theoretical sociology: anthology. Moscow: book house "University".

Suslov, V.G. (2008). Problems of inclusive education: preparation of the future geography teacher for correctional and pedagogical activity. Geography and ecology in the school of the XXI century, 8, 61-65.

Volkova, L.S. (2002). Some problems of integrated education in Russian defectology at the present stage. Defectology, 3, 3-8.

Voznyak, I.V. \& Dubinina, V.V. (2009). Municipal model of integrated education for children with disabilities in Belgorod. Speech therapist in kindergarten, 1, 22-32.

Vygotsky, L.S. (1997). Fundamentals of defectology. Moscow: Prosveshchenie.

Yarskaya-Smirnova, E.R. \& Loshakova, I.I. (2003). Inclusive education of disabled children. Sociological research, 5, 100-106.

Zotova, A.M. (1997). Integration of a disabled child into the environment of healthy peers as a method of social adaptation. Defectology, 6, 21-25.

Zykova, T.S. (2005). Schools for deaf and hard of hearing children at the stage of education modernization. Defectology, 5, 31-36. 